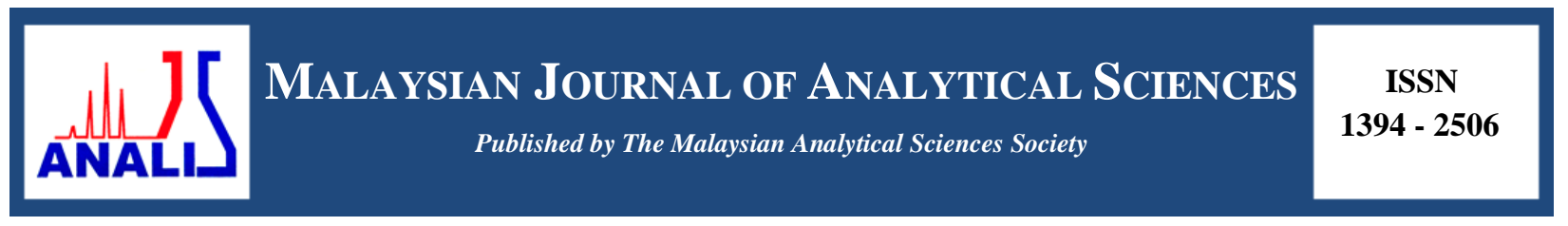

\title{
LIQUID CHROMATOGRAPHY TANDEM MASS SPECTROMETRY FOR THE DETECTION AND VALIDATION OF QUERCETIN-3-O-RUTINOSIDE AND MYRICETIN FROM FRACTIONATED Labisia pumila var. alata
}

\author{
(Kromatografi Cecair Spektrometri Jisim Tandem untuk Pengesanan dan Pengesahsahihan \\ Kuersetin-3-O-Rutinosida dan Mirisetin daripada Pemeringkatan Labisia pumila var. alata) \\ Norliza Abdul Latiff ${ }^{1,3}$, Chua Lee Suan ${ }^{2}$, Mohammad Roji Sarmidi ${ }^{3}$, Ismail Ware ${ }^{1}$, \\ Siti Nur Azlina Abdul Rashid ${ }^{1,3}$, Maizatulakmal Yahayu ${ }^{1}$ \\ ${ }^{1}$ Institute of Bioproduct Development \\ ${ }^{2}$ Faculty of Chemical and Energy \\ Universiti Teknologi Malaysia, 81310 Johor Bahru, Johor, Malaysia \\ ${ }^{3}$ Innovation Centre in Agritechnology for Advanced Bioprocessing, \\ Universiti Teknologi Malaysia, 84600 Pagoh, Johor, Malaysia \\ *Corresponding author: norliza@ibd.utm.my
}

Received: 6 August 2018; Accepted: 24 September 2018

\begin{abstract}
Quercetin-3-O-rutinoside and myricetin was reported to be important secondary metabolites in Labisia pumila (L. pumila). The reliability of the instrument, its sensitivity and methodology are the key in the analysis of a specific metabolite and liquid chromatography tandem mass spectrometry (LC-MS/MS) provides better accuracy and faster separation in detecting of such chemical compound. Therefore, this study aims to detect and validate the presence of quercetin-3-O-rutinoside and myricetin from fractionated extract of L. pumila $\left(40 \% \mathrm{MeOH}\right.$ : water). The plant material was fractionated using octadecyl $\left(\mathrm{C}_{18}\right)$ silica solid phase and eluent with a ratio of $40 \% \mathrm{MeOH}$ : water. The separation of compounds was carried out using a $\mathrm{C}_{18}$ reversed phase column (Acquity, $150 \mathrm{~mm} \times 4.6 \mathrm{~mm} \times 1.7 \mu \mathrm{m}$ ). Negative ionization was utilized to fragment the precursor ion of $\mathrm{m} / z$, $609 \mathrm{for}$ quercetin-3-O-rutinoside and $m / z, 317$ for myricetin. Three fragments ions; $m / z, 447,463,301$ was recognized as quercetin-3-Orutinoside product ions within 3.3 minutes. Meanwhile, $\mathrm{m} / \mathrm{z}, 271,137$ and 151 represented characteristics ions for myricetin were recognized within 3.9 minutes. The concentration of quercetin-3- $O$-rutinoside and myricetin was $0.007 \mathrm{mg} / \mathrm{g}$ and $0.009 \mathrm{mg} / \mathrm{g}$ respectively. The linearity was found between 0.991-0.998. Detection based on (limit of detection) LOD and (limit of quantification) LOQ were found in the ranged of 0.03-0.04 $\mu \mathrm{g} / \mathrm{mL}$ and $0.11-0.13 \mu \mathrm{g} / \mathrm{mL}$, respectively. Both compounds showed good recovery of above $87 \%$. Intra-day and inter-day (RSD) study was in the acceptable range (below 10\%). Based on the result of this study, the LC-MS/MS was shown to be the best selective, fast and sensitive method to determine quercetin-3-O-rutinoside and myricetin in the plant fraction. These findings could be used as a guideline for the detection of the compounds and suitable for quality controls of $L$. pumila this and another medicinal herb containing quercetin-3-O-rutinoside and myricetin.
\end{abstract}

Keywords: Labisia pumila, quercetin-3-O-rutinoside, myricetin, validation

\begin{abstract}
Abstrak
Kuersetin-3-O-rutinosida dan mirisetin telah dilaporkan sebagai metabolit sekunder yang penting dalam Labisia pumila ( $L$. pumila). Kebolehpercayaan instrumen, kepekaan dan kaedah pembangunan menjadi aspek penting dalam analisis yang disasarkan kepada metabolit tertentu dan kromatografi cecair spektrometri jisim tandem (KC-SJ/SJ) menyediakan pengasingan lebih cepat dan tepat bagi pengesanan sebatian kimia. Oleh itu, kajian ini adalah bertujuan untuk mengesan dan menentusahkan kehadiran kuersetin-3-O-rutinosida dan mirisetin daripada pemeringkatan L. pumila (40\% metanol:air). Bahan tumbuhan ini
\end{abstract}




\section{Norliza et al: LIQUID CHROMATOGRAPHY TANDEM MASS SPECTROMETRY FOR THE DETECTION AND VALIDATION OF QUERCETIN-3-O-RUTINOSIDE AND MYRICETIN FROM FRACTIONATED Labisia pumila var. alata}

diperingkatkan menggunakan fasa pepejal oktadesil silika $\left(\mathrm{C}_{18}\right)$ dengan kadar $40 \%$ metanol: air. Pengasingan komponen dicapai menggunakan fasa turus berbalik $\mathrm{C}_{18}$ (Acquity, $150 \mathrm{~mm} \times 4.6 \mathrm{~mm} \times 1.7 \mu \mathrm{m}$ ). Pengionan negatif telah digunakan untuk mengasingkan pencetus ion $\mathrm{m} / \mathrm{z}, 609$ untuk kuersetin-3-O-rutinosida dan $\mathrm{m} / \mathrm{z} 317$ untuk mirisetin. Tiga pecahan ion; $\mathrm{m} / \mathrm{z}, 447,463$, 301 dikenal pasti sebagai produk molekul ion dari kuersetin-3-O-rutinosida dalam selang masa 3.3 minit. Manakala $m / z, 271,137$ and 151 mewakili ciri ion untuk mirisetin telah dikenalpasti dalam selang masa 3.9 minit. Kepekatan kuersetin-3-O-rutinosida dan mirisetin masing-masing ialah $0.007 \mathrm{mg} / \mathrm{g}$ dan $0.009 \mathrm{mg} / \mathrm{g}$. Kelinearan adalah di antara 0.991-0.998. Had pengesanan (LOD) dan had pengkuantitian (LOQ) adalah masing-masing dalam julat 0.03-0.04 $\mu \mathrm{g} / \mathrm{mL}$ dan $0.11-0.13 \mu \mathrm{g} / \mathrm{mL}$. Kedua-dua sebatian menunjukkan penghasilan yang baik, lebih daripada $87 \%$. Kajian dalam-hari dan antara-hari (RSD) adalah dalam julat yang boleh diterima (bawah 10\%). Berdasarkan keputusan melalui kajian ini, KC-SJ/SJ ditunjukkan sebagai kaedah terpilih, cepat dan sensitif bagi menentukan kuersetin-3-O-rutinosida dan mirisetin di dalam pemeringkat tumbuhan ini. Penemuan ini boleh digunakan sebagai panduan untuk pengesanan sebatian dan sesuai sebagai kawalan kualiti untuk L. pumila dan herba perubatan yang lain yang mengandungi kuersetin-3-O-rutinosida and mirisetin.

Kata kunci: Labisia pumila, kuersetin-3-O-rutinosida, mirisetin, pengesahsahihan

\section{Introduction}

Labisia pumila (L. pumila) is known as the best Malaysian herbal recognized in various medical benefits especially for women. Locally known as Kacip Fatimah (Myrsinaceae), it is a traditional herbal plant widely used by peoples from the Asian region, especially in Malaysia and Indonesia. This plant is exclusive for women's health due to the presence of phytoestrogen. It can relief menopausal syndrome as well as health booster during post-delivery and it is also suitable to be used during pregnancy [1-6]. Furthermore, it was reported earlier that the aqueous plant extract could assist in modulating the post-menopause adiposity in ovariotamized rats and the result was comparable to the estrogenic receptor replacement therapy (ERT) [7]. There was also no acute toxicity reported for the treatment of post-menopausal symptom based on the clinical studies conducted [8]. Additionally, the plant's root aqueous extract was also found to be effective in osteoporosis treatment [9] as it showed significant modulation effect in pharmacokinetic and pharmacodynamics properties [10]. Interestingly, the value of anti-aging and antioxidant property of the L. pumila has surged its application as acosmeceutical agent [11-14]. The plant aqueous extract also showed a prospective application as anticancer, anti-inflammatory and anti-fungal agent $[13,15]$. The three types of L. pumila variety were recognized worldwide as alata, pumila and lanceolata [16] and the former two varieties were selected as most important valued sources due to its significant medicinal properties [3].

Recently, many types of phytochemicals have been identified from the leaves, roots and whole plant parts of $L$. pumila [13-15, 17-21]. Based on the analytical studies using various detection techniques, it was shown that the plant extract contained significant amount of polyphenols and the sub-group of polyphenols; flavonoids was the major constituents. In our initial work, qualitative analysis of $L$. pumila var. alata from the methanolic extract using LC-MS/MS in profiling 20 polyphenols constituents has been achieved [22]. Quercetin-3-O-rutinoside and myricetin have shown by its significant peaks in the chromatogram. In other related publication, the presence of these compounds was also detected in leaves and roots of the same plant variety $[13,14,17,18]$. These compounds were the most beneficial flavonoids and commonly used in food and beverages and it was used and registered in over 130 medicinal formulations for its therapeutic effect [23]. In addition, the pharmacological properties of quercetin-3-O-rutinoside as anti-cancer, antioxidant, antidiabetic and anti-inflammatory agent were also studied [23]. From cosmeceutical view, quercetin-3-O-rutinoside has the sun light blocking properties as well as the ability to prevent skin diseases such as redness and skin lesions [24]. Myricetin were also used as a chemotaxonomic marker in Chrysobalanaceae family [25]. Relevant pharmacological activity from this compound has been reported earlier [25-26].

From the literature review, analytical procedure that has been developed to identify and quantify the quercetin-3-Orutinoside and myricetin was using HPLC [13, 17]. However, high sensitivity and resolution with accurate mass can only be achieved using mass spectrum. Still, analysing complex matrices have become a challenge to create consistent signal in every sample injection. The use of LC-MS/MS with triple quadrupoles ion trap for quantitation offer faster and accurate results. Hence, it is essential to developed new analytical procedures that provide good compound resolution and sensitivity to identify quercetin-3-O-rutinoside and myricetin from plant. This analytical technique could be used together with chemical and biological assays of natural products. 
The aim of this study was to develop a LC-MS/MS method to identify quercetin-3- $O$-rutinoside and myricetin. The quantitative results were further validated in this study for quality control purposes. Prior to analysis, to reduce sample matrix in the complex mixture, preparative fractionation by using packed $\mathrm{C}_{18}$ column bed in the solid phase extraction (SPE) technique were used after the extraction process [22-27]. The analytical method developed could be essential for the discovery of natural product especially to identify quercetin-3-O-rutinoside and myricetin from $L$. pumila and other herbal plants.

\section{Chemicals}

\section{Materials and Methods}

Reagent grade methanol $(\mathrm{MeOH})$ was purchased from Fisher Scientific (Pittsburgh, PA). HPLC grade methanol and acetonitrile were obtained from Merck (Darmstadt, Germany). Ultra-pure water was from a Barnstead Nano-pure Diamond water purification system (Thermo, Waltham, MA). The deionized water was produced from Barnstead Epure water system (Thermo, Waltham, MA). The chemical standards of quercetin-3-O-rutinoside and myricetin were procured from Sigma-Aldrich (St Louis, MO) and the SPE cartridge, Strata ${ }^{\mathrm{TM}}$-X, (8B-S029 FBJ, $200 \mathrm{mg}$ ) was purchased from the local supplier (Phenomenex, Torrance, CA).

\section{Plant material: Sources and preparation}

L. pumila var. alata which was labeled as FRI 59810 was freshly taken from the herbal farm at Forest Research Institute Malaysia (FRIM), Selangor. After harvesting, the leaves were dried using conventional drying oven at 40 ${ }^{\circ} \mathrm{C}$ for 24 hours. The dried leaves were ground (mesh size approximate 200 micron) by using a warring blender and kept in seal plastic before storage at $-20{ }^{\circ} \mathrm{C}$, prior to further analysis.

\section{Fractionation of $L$. pumila by solid phase extraction}

The extraction and fractionation method were done based on method established by Chua et al. [22]. The fractionation of $L$. pumila was done by using $\mathrm{C}_{18}$ sorbent type material. The SPE cartridge, Strata ${ }^{\mathrm{TM}}-\mathrm{X}$, (8B-S029 FBJ, $200 \mathrm{mg}$ ) was procured from local supplier (Phenomenex, Torrance, CA). In this procedure, $40 \% \mathrm{MeOH}$-water mixture was used as the eluting solvent. The crude extract $(50 \mathrm{mg})$ was suspended in $5 \mathrm{~mL} \mathrm{MeOH}$. The mixture was vortexed to allow homogenization. The homogenized mixture $(2 \mathrm{~mL})$ was further diluted with $3 \mathrm{~mL}$ of deionized water. The fractionation process was started by conditioning the cartridges with $15 \mathrm{~mL}$ of $100 \% \mathrm{MeOH}$ and followed by $15 \mathrm{~mL}$ of deionized water, at a control flow rate of $10 \mathrm{~mL} / \mathrm{min}$, under vacuum. This procedure is important to remove the air bubbles trapped inside the cartridge. The sample $(2 \mathrm{~mL})$ was then added to the SPE cartridge at slow flow rate of $1 \mathrm{~mL} / \mathrm{min}$. An amount $5 \mathrm{~mL}$ of 5:95 MeOH: water in ratio 5:95 was loaded into the cartridge to remove the impurities. The fraction was then collected upon elution with $40 \% \mathrm{MeOH}$-water $(15 \mathrm{~mL})$. The fraction was dried using rotary evaporator and finally weighed and stored in the refrigerator before further analysis.

\section{LC-MS/MS analysis}

The method is referred from established method by Chua et al. [22] with minor changes for improvement. The plant fraction $(10 \mathrm{mg})$ was diluted with $10 \mathrm{~mL} 40 \% \mathrm{MeOH}$-water. The sample was vortexed to homogenise and filtered using $0.20 \mu \mathrm{m}$ syringe filters (Nylon membrane, Titan, Thermo Scientific, Germany). The filtered solution ( $1 \mathrm{~mL}$ ) was inserted into HPLC vial to be injected into LC-MS/MS system. Chromatographic separation was done by using an Acquity, system (Waters Corporation, Milford, MA) and an Acquity reversed phase $\mathrm{C}_{18}$ column $(150 \mathrm{~mm} \times 4.6$ $\mathrm{mm} \times 1.7 \mu \mathrm{m}$ particle size) from Waters (Milford, MA). The detection was done via mass spectrometry 4000 QTRAP (Applied Biosystems-AB Sciex, Life Technologies Corporation, Carlsbad, CA). The analysis of the fraction was performed using the Analyst software (version 1.4.2). Gradient system was used to elute the sample before entering the mass spectrometry system. The mobile phase A consists of $0.1 \%$ formic acid in water and $0.1 \%$ formic acid in acetonitrile for mobile phase B. The mobile phase was developed using gradient system at $0-5$ minutes, 10\% B; 5-15 minutes, 10-90\% B; 15-20 minutes, 90\%B; 20-25 minutes, 90-10\% B; 25-30 minutes, $10 \%$ B for the final wash and column equilibration before the next injection. The injection volume was $5 \mu \mathrm{L}$. The mobile phase was filtered using $0.2 \mu \mathrm{m}$ nylon membrane filter. The flow rate was set at $0.25 \mathrm{~mL} / \mathrm{min}$ and system was run at 15 minutes. 


\section{Norliza et al: LIQUID CHROMATOGRAPHY TANDEM MASS SPECTROMETRY FOR THE DETECTION AND VALIDATION OF QUERCETIN-3-O-RUTINOSIDE AND MYRICETIN FROM FRACTIONATED Labisia pumila var. alata}

The mass spectrometry (MS/MS) was done by using electrospray ionization (ESI) in negative and positive ion mode. The mass spectra were acquired with the ranges molecular weight $(\mathrm{m} / \mathrm{z})$ of 100-1500 with 20 mass ion accumulations. The capillary and voltage of the ESI source were maintained at $400{ }^{\circ} \mathrm{C}$ and $4.5 \mathrm{kV}$, respectively (both negative and negative mode). The ESI parameters used were as follows: nitrogen was used as ion source gas for nebulization at $40 \mathrm{psi}$; solvent drying at $40 \mathrm{psi}$; nitrogen gas was set at $10 \mathrm{psi}$; collision gas was set at high; declustering potential of 30-50 V, and collision exit energy, 10-20 V. The scan rate was $100 \mathrm{amu} / \mathrm{s}$. A low energy collision dissociation (CID) was used in quantitative by multiple reactions monitoring (MRM) mode. The MRM mode was used to generate the standard curve from a standard compound of aglycone. To develop the mass spectrum from targeted compounds, the compounds were directly delivered into ESI source. This procedure was called as the direct infusion where the sample was directly injected to the mass detector. Manual injection was done by using syringe pump and the injection flow rate was $0.5 \mathrm{~mL} / \mathrm{min}$ at $1 \mu \mathrm{g} / \mathrm{mL}$.

\section{Validation of the quercetin-3-O-rutinoside and Myricetin}

According to European Analytical Chemistry (EURACHEM) guideline for method validation, the fundamental of validation includes accuracy, precision, recovery, selectivity, calibration curve and stability [28]. This fundamental work can be applied todetermine the quantity of metabolites from the complex matrices. The EURACHEM guidance provides general references on the best practice of chemical analysis and its criteria can be selected depending on the specific test and analytical method applied. The validation of the quercetin-3-O-rutinoside and myricetin was selected based on four criteria which are the calibration curve, sensitivity, accuracy, and precision, as suggested $[28,29]$.

\section{Linearity}

Linearity was evaluated through the determination of six standards working solutions containing $0.1-100 \mu \mathrm{g} / \mathrm{mL}$ of the standard compounds in triplicate preparations. The peak area and concentration were subjected to least-squares linear regression analysis to calculate the calibration equation and correlation coefficients.

\section{Accuracy}

The accuracy was calculated through the recovery studies by adding a known amount of the solution of each standard compound into triplicate aliquots of extract. The sample and the spiking solutions were followed by the fractionation process before subjected to LCMS/MS analysis. The recovery of the standard compounds was calculated in the percentage unit. Recovery of the standard compounds was calculated in percentage as follows:

$$
\text { Recovery }(\%)=\frac{\mathrm{C} 1-\mathrm{C} 2}{\mathrm{C} 3}
$$

where $\mathrm{C} 1$ is define as concentration of spiked sample, $\mathrm{C} 2$ is concentration of sample and $\mathrm{C} 3$ is concentration of the standard solution.

\section{Sensitivity}

The sensitivity of the method was evaluated by utilizing the limit of detection (LOD) and limit of quantitation (LOQ) analysis. The LOD was described as the minimum detection (signal) of instrument response a significant difference between background, blank and analyte signals [28]. LOQ was described as the quantitative result which can be reported at a high degree of confidence. The LOD and LOQ of the LCMS/MS method for the standards were established at a standard deviation of the average value of 3 and 10, respectively, which were experimentally verified by six injections of each of the substances at the LOQ concentrations.

\section{Precision}

To study the precision, the analysis was carried out in intra-day and inter-day with the aim to produce reproducibility. The aliquots were subjected to LCMS/MS injection. For intra-day studies, aliquots were injected at four different times on the same day. The peak area was analyzed and compared between injection samples at 4 different times. The percentage of the relative standard deviation (\% RSD) was calculated. The inter-day studies were evaluated by injecting the aliquots on the first day, second day, after 1 week and after 1 month. The good reproducibility for the investigated compounds was observed, which is evident by the RSD value which was less than $10 \%$. 


\section{Optimization of LC-MS/MS}

\section{Results and Discussion}

The $40 \% \mathrm{MeOH}$-water fraction of $L$. pumila was found having glycosides which include quercetin-3-O-rutinoside [22]. Further detection of quercetin-3-O-rutinoside and myricetin to improved quantitative analysis is necessary. In this study, several parameters were considered for compound optimization which basically signalled by the chromatographic separation as well as the mass spectra that was used for the compound characterisation. The parameter of the mobile phase was investigated using both isocratic and gradient separation. The isocratic separation was done via a combination of mobile phase A and mobile phase B consisting of mixtures of water: acetonitrile and water-methanol. The compound resolution using water: methanol (90:10) mixture was found to be lower when compared with the water-acetonitrile (90:10) mixture using isocratic separation system. The gradient system employed could improve the compounds resolution and eliminate the effect of peak tailing. The addition of low concentration, of $0.1 \%$ formic acid was able to improve the chromatographic feature and the mass spectra quality. Therefore, $0.1 \%$ formic acid was added into water as mobile phase A and into acetonitrile as mobile phase $\mathrm{B}$ in the gradient system with the system set at a fast flow rate; $0.25 \mathrm{~mL} / \mathrm{min}$. Fast separation was obtained between 10 minutes for both quercetin-3-O-rutinoside and myricetin. The ratio of mobile phase A and B was 90:10 for the first elution and was changed to 10:90 after 3 minutes and stay to equilibrate in the system for the next 6 minutes before return to the initial ratio in 8.10 to 10 minutes in a total runtime.

The MS/MS detection method for product ion characterisation was designated to acquire the mass signal. In this study, the mass was set up to render the mass of interest. The identification of product ion for compound verification was done by enhancing the product ion (EPI) scan mode. Different energy was used to produce ion from the electro-spray ionisation (ESI) source. The parameter included studying entering declustering potential (DP, Volt, V) and collision exit energy (CE, Volt, V) before it was identified. Meanwhile, the quantification of quercetin3-O-rutinoside and myricetin were done using the multiple reaction monitoring (MRM) scan mode. This MRM scan mode is the best operational mode to localize the accuracy with specific ion fragmentation from the precursor ion (by mean parent ion) to its specific fragmentation ion (by mean daughter ion). The DP energy was set up from 30$50 \mathrm{~V}$ which is from high to lower energy. Meanwhile, CE was acquired from 10-20 V. Negative fragmentation produced better sensitivity detection signal for quercetin-3-O-rutinoside. The optimized DP energy for EPI scan mode was achieved at $40 \mathrm{~V}$, while CE at $10 \mathrm{~V}$. The optimized DP and CE for MRM scan mode were accomplished at $50 \mathrm{~V}$ and $20 \mathrm{~V}$, correspondingly for both mass of interests.

Figure 1 showed the molecular ion $\mathrm{m} / \mathrm{z} 609$ at two different DP energy which produce characteristics ions of $\mathrm{m} / \mathrm{z}$ $463,447,301,271,285,179$ and 151 . The presence of four ions, $\mathrm{m} / z, 271,285,179$ and 151 were attributed to the major characteristics of quercetin [30]. The mass spectra showed an intense peak with clear characteristics ions at DP $40 \mathrm{~V}$ rather than DP $55 \mathrm{~V}$ with reference to the Figure 1. However, by increasing the DP energy, the product of quercetin was fragmented to intense quercetin peaks, however, the other three peaks of $\mathrm{m} / z, 463,447$ and 609 had disappeared from the mass spectrum. From the EPI mass spectral, the loss of $146 \mathrm{Da}$ (rhamnoside residual) from $\mathrm{m} / \mathrm{z} 609$ formed the $\mathrm{m} / \mathrm{z} 463$, and occurrence of $\mathrm{m} / \mathrm{z} 447$ was due to the cleavage of glucoside unit (162 Da) from the main quercetin structure. It was reported that $\mathrm{m} / z 609$ was quercetin-3-O-rutinoside [31]. The loss of galactose, glucose or mannose from $\mathrm{m} / \mathrm{z}, 609$ showed a significant peak at $\mathrm{m} / \mathrm{z} 463$ which was similar with previous article reported by Abad and his team [31]. The peak corresponding to $m / z 463$ was identified as quercetin-3-O-galactoside [30,32]. The presence of $m / z 447$ was designated as quercitrin or commonly known as a quercetin-3-rhamnoside where one type of sugar was attached to its basic aromatic rings. The $\mathrm{m} / z 447$ corresponded to the loss of one-unit sugar (146 Da) to form the quercetin $\mathrm{m} / z, 301$ together with the product ion $\mathrm{m} / z .179$ and $\mathrm{m} / \mathrm{z} 151$ [30, 33]. The rhamnose unit was easily deprotonated with the loss of $146 \mathrm{Da}$, resulting in fragments at $\mathrm{m} / \mathrm{z} 301,179$ and 151 (Figure 1). Pikulski and Brodbelt [33] reported that the deprotonation of quercitrin apparently by homolytic bond cleavage. This compound was commonly found in Brazilian cherry and South America berries fruits [32,34]. 
Norliza et al: LIQUID CHROMATOGRAPHY TANDEM MASS SPECTROMETRY FOR THE DETECTION AND VALIDATION OF QUERCETIN-3-O-RUTINOSIDE AND MYRICETIN FROM

FRACTIONATED Labisia pumila var. alata

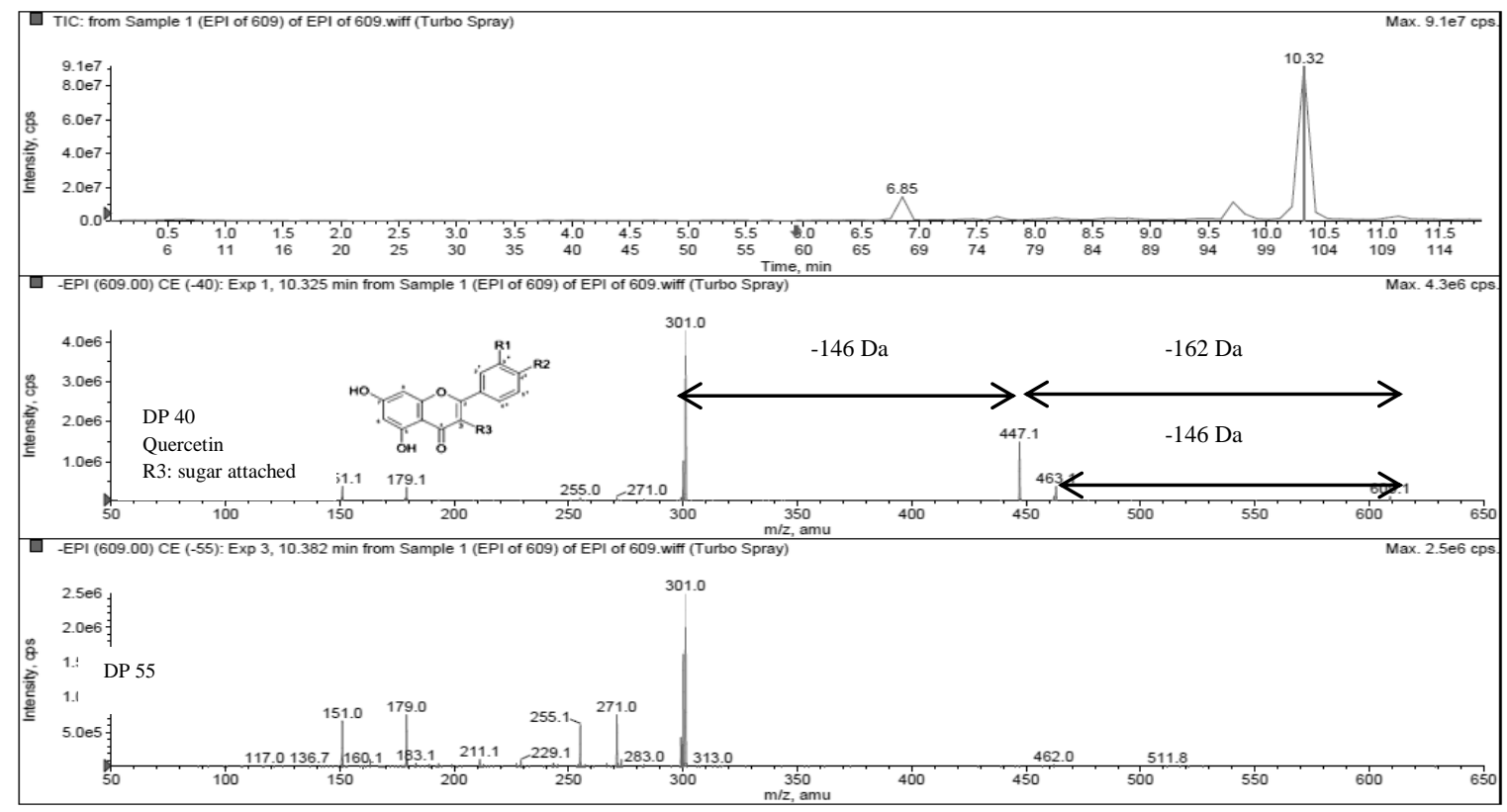

Figure 1. EPI mass spectra of quercetin-3-O-rutinoside from L. pumila fraction (40\% $\mathrm{MeOH}$ : water) at different DP energy (DP $40 \mathrm{~V}$ and DP $55 \mathrm{~V}$ )

Identification of quercetin-3- $O$-rutinoside and myricetin from the fraction

Identification of quercetin-3-O-rutinoside and myricetin were carried out in negative and positive ionisation mode by comparing the MS/MS spectra in EPI scan. The $[\mathrm{M}-\mathrm{H}]^{-}$was selected because it produces extensive MS/MS fragmentation compare to $[\mathrm{M}+\mathrm{H}]^{+}$. Quercetin-3-O-rutinoside $(\mathrm{m} / \mathrm{z}, 610)$ has loss 1-unit hydrogen in $[\mathrm{M}-\mathrm{H}]^{-}$ producing $\mathrm{m} / \mathrm{z} 609$ as shown in Figure 1. Myricetin $(\mathrm{m} / \mathrm{z}$ 318) has also loss 1 unit of hydrogen to formed molecular ion, $m / z 317$ (Figure 2). The structure of quercetin-3-O-rutinoside and myricetin were shown in Figure 3.

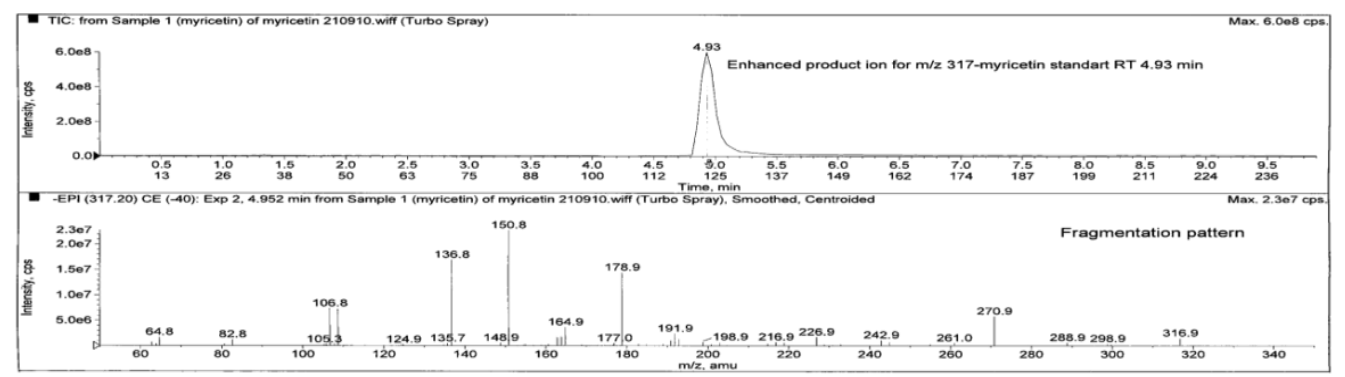

Figure 2. The EPI mass spectra of myricetin L. pumila fraction (40\% MeOH: water) at different DP energy (DP $40 \mathrm{~V}$ and DP $55 \mathrm{~V}$ ) 


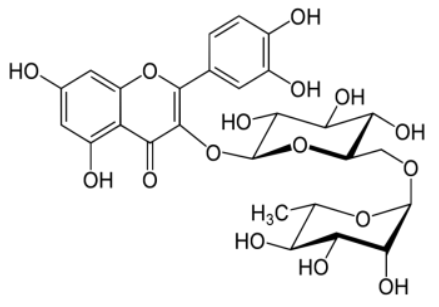

Quercetin-3-O-rutinoside

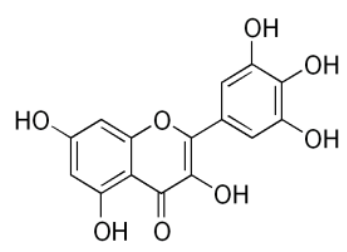

Myricetin

Figure 3. Structure of quercetin-3-O-rutinoside and myricetin

Myricetin with molecular ion $m / z 318$ was ionised leading to loss 1 unit of hydrogen to generate negative ion [M-H] $\mathrm{m} / \mathrm{z} 317$ which was then fragmented to four characteristics ion of $m / z 271,179,151,137$ (Figure 1) that is similar to the aglycone of quercetin. This occurrence was due to the breakdown of the aglycone myricetin structure, with the loss of $92 \mathrm{Da}, 28 \mathrm{Da}\left(2 \mathrm{CH}_{2}\right)$ and $14 \mathrm{Da}\left(\mathrm{CH}_{2}\right)$ with reference to the formation of peaks of $\mathrm{m} / z 179,151$ and 137 , respectively. The presence of two peaks of $\mathrm{m} / \mathrm{z} 179$ and 151 were attributed to the major characteristics ion of myricetin $[35,36]$. These four product ions were then confirmed by MRM scan, where consistent fragment ions matched to the standard myricetin. Myricetin is a flavonol-type which consists of three hydroxyl groups located at the $\mathrm{B}$ ring at position 3,4 and 5. The sugar unit was attached to its basic aromatic ring to form a myricetin glycosides. This compound was also presence in fruits such as cherry, grapes and cranberry [25, 32, 37]. Our experiments showed that the best DP energy to generate the product ion was $40 \mathrm{~V}$ and the CE was at $40 \mathrm{~V}$.

From the study, $40 \% \mathrm{MeOH}$ fraction contained quercetin-3-O-rutinoside and myricetin and the presence of product ion is essential for the characterisation of these compounds. The generated DP energy at 40V was the most optimum energy to generate the product ion for both compounds in the enhance product ion scan mode (EPI).

\section{Quantification and validation}

The quantification step was done by using MRM scan to generate peaks from the precursor ion to product ion. Fragment of $m / z, 301$ is the dominant product ion over quercetin-3-O-rutinoside. Meanwhile, $\mathrm{m} / \mathrm{z}, 137$ was selected for myricetin in MRM scan mode. Using fast and accurate MRM scan mode, chromatographic data for both compounds including retention time, peak area, and peak height were monitored. As a requirement to verify and quantify the presence of these compounds, a standard working solution of quercetin-3-O-rutinoside and myricetin ( $99 \%$ purity) was used to build a standard calibration curve.

The peak of quercetin-3-O-rutinoside was detected at 3.3 minutes with a total running time of 10 minutes (Figure 4). The concentration of quercetin-3-O-rutinoside was determined to be at $0.007 \mathrm{mg} / \mathrm{g}$ in the plant fraction. Meanwhile, myricetin was detected at 3.9 minutes with the total running time set at 10 minutes (Figure 5). Significantly, myricetin was found to be higher in this plant fraction as compared to quercetin-3-O-rutinoside which was at 0.009 $\mathrm{mg} / \mathrm{g}$ in the plant fraction. 


\section{Norliza et al: LIQUID CHROMATOGRAPHY TANDEM MASS SPECTROMETRY FOR THE DETECTION AND VALIDATION OF QUERCETIN-3-O-RUTINOSIDE AND MYRICETIN FROM \\ FRACTIONATED Labisia pumila var. alata}

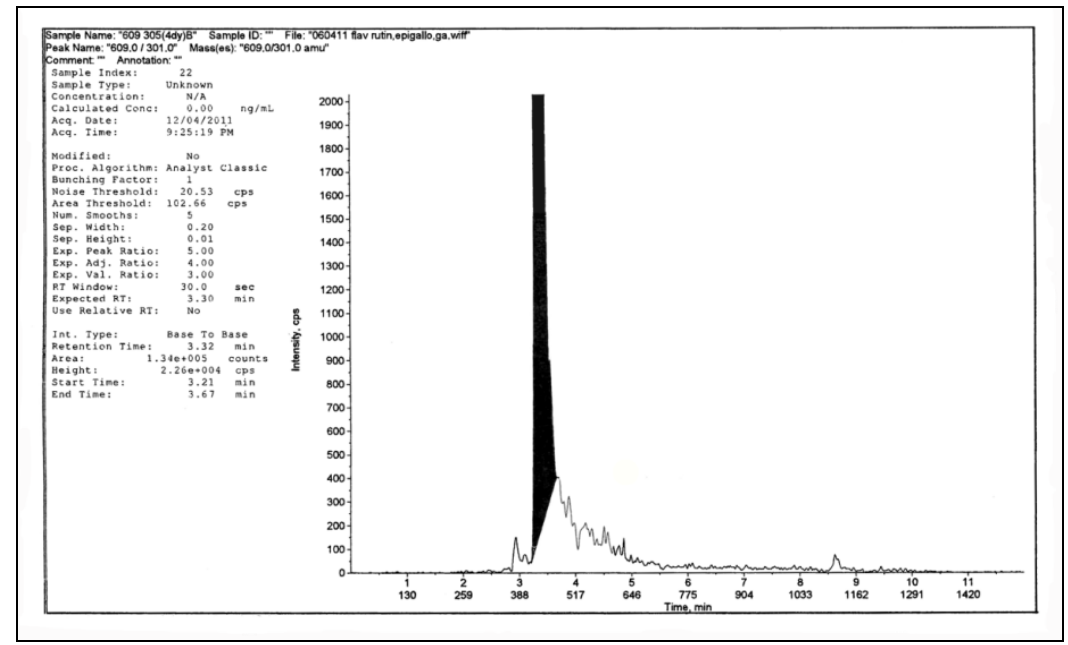

Figure 4. The MRM peak of quercetin-3-O-rutinoside from the $L$. pumila in $40 \% \mathrm{MeOH}$ : water fraction

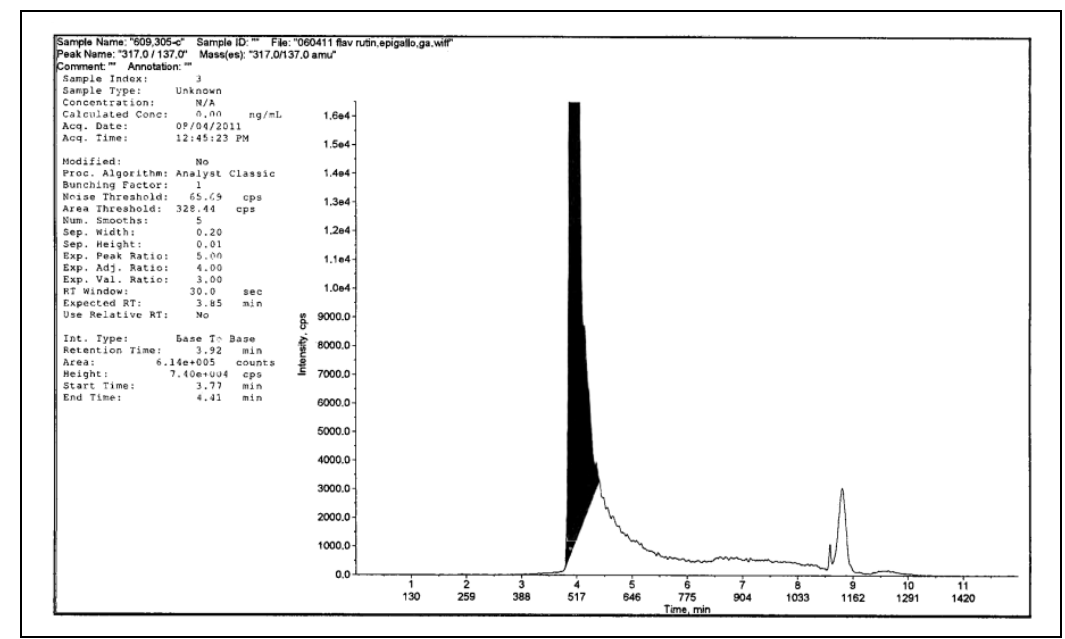

Figure 5. The MRM peak of myricetin from the L. pumila in $40 \% \mathrm{MeOH}$ : water fraction

The LC-MS/MS validated method was determined based on its linearity, LOD, LOQ, precision and accuracy according to the guideline [28] suitable for quality control (Table 1 ). The response of quercetin-3-O-rutinoside in the range of $0.1-100 \mu \mathrm{g} / \mathrm{mL}$ produced linearity result with good regression equation and correlation coefficient $\left(\mathrm{r}^{2}=\right.$ 0.998 with the following equation; $y=99956 \mathrm{x}-89337)$. The detection limit, LOD and LOQ for the quercetin-3-Orutinoside were $0.04 \mu \mathrm{g} / \mathrm{mL}$ and $0.13 \mu \mathrm{g} / \mathrm{mL}$, respectively. The developed LC-MS/MS method had successfully achieved high sensitivity detection of quercetin-3-O-rutinoside based on the LOD and LOQ which were comparable to the signal noise to ratio $(\mathrm{S} / \mathrm{N})$. This method was found fit for quantitation purpose. The recovery for quercetin-3$O$-rutinoside was measured at $87 \%$ and most probably the $13 \%$ loss was probably due to the steps involved during the sample preparation. However, it can be considered as a good compound recovery since the percentage was above $80 \%$. Good precision was expressed by the RSD (\%) value, which is required to be less than $10 \%$. The intraday and inter-day for quercetin-3-O-rutinoside were found to be $5.01 \%$ and $9.18 \%$, respectively. These two values showed that quercetin-3-O-rutinoside was stable for at least a month, but it is recommended to prepare the extract fresh for analysis to avoid any deterioration. 
The detection method for myricetin was described based on the optimal detection condition (not shown). The calibration curve in order to obtain the linearity of myricetin was found to be straight linear concentration ranged from 0.1 to $100 \mu \mathrm{g} / \mathrm{mL}$ and had a linear regression of $\mathrm{r}^{2}=0.991$ with the following equation; $\mathrm{y}=35125 \mathrm{x}-13273$. The LOD and LOQ for myricetin were found to be at $0.03 \mu \mathrm{g} / \mathrm{mL}$ and $0.11 \mu \mathrm{g} / \mathrm{mL}$, respectively. Analysis of the spiked myricetin standard for recovery study had showed an average recovery of $88.2 \%$. The analysis of the compound in the solution on the same day had shown good reproducibility at $3.14 \%$. The study on the different days (inter-day) also showed good precision of $3.18 \%$. Therefore, the robustness of the method indicated that myricetin is possibly consistent for at least 1 month of storage based on these results. Table 1 summarises the results from the study.

Table 1. Linearity, LOD, LOD, recovery, intra-day and inter-day data of quercetin-3- $O$-rutinoside and myricetin in L. pumila fraction ( $40 \% \mathrm{MeOH}$ : water) by LC-MS/M

\begin{tabular}{llcccccc}
\hline Flavonoids & Linear Equations & $\begin{array}{c}\text { LOD } \\
(\boldsymbol{\mu g} / \mathbf{m L})\end{array}$ & $\begin{array}{c}\text { LOQ } \\
(\boldsymbol{\mu} \mathbf{g} / \mathbf{m L})\end{array}$ & $\begin{array}{c}\text { Recovery } \\
(\boldsymbol{\%})\end{array}$ & $\begin{array}{c}\text { Intra- } \\
\mathbf{d a y} \\
(\mathbf{R S D})\end{array}$ & $\begin{array}{c}\text { Inter- } \\
\mathbf{( \mathbf { R S D } )} \\
\mathbf{\%}\end{array}$ & $\begin{array}{c}\text { Concentration } \\
(\mathbf{m g} / \mathbf{g})\end{array}$ \\
\hline $\begin{array}{l}\text { Quercetin-3-O-rutinoside } \\
\text { Myricetin }\end{array}$ & $\mathrm{Y}=99956 \mathrm{x}-89337$ & 0.04 & 0.13 & 87.00 & 5.01 & 9.18 & 0.007 \\
& $\mathrm{Y}=35125 \mathrm{x}-13273$ & 0.03 & 0.11 & 88.20 & 3.14 & 3.18 & 0.009 \\
\hline
\end{tabular}

\section{Conclusion}

The present work describes the application of LC-MS/MS procedure to analysed quercetin-3-O-rutinoside and myricetin in L. pumila fraction which was obtained from $40 \% \mathrm{MeOH}$ : water. The validated method indicated that lower concentration of quercetin-3-O-rutinoside and myricetin can be identified and quantified in the plant fraction by using high throughput analytical technique via electrospray ionisation (ESI). Valuable information can be provided including mass identity together with characteristics fragmentation ion. This method is applicable for the analysis of plant containing quercetin-3-O-rutinoside and myricetin as well as for quality control and routine analysis purposes.

\section{Acknowledgment}

The authors would like to express Universiti Teknologi Malaysia for the financial assistant under Research University Grant (GUP) Q.J130000.2609.11J53 and Institute of Bioproduct Development for facilities provided.

\section{References}

1. Ezumi, M. F. W., Siti Amrah, S., Suhaimi, A. W. M. and Mohsin, S. S. J. (2007). Evaluation of female reproductive toxicity of aqueous extract of Labisia pumila var. alata in rats. Indian Journal of Pharmacology, 39(1): 30-32.

2. Burkill, I. H. (1935). A dictionary of the economic products of Malay peninsula, Crown Agent, London, UK.

3. Jamal, J. A., Houghton P. J., Milingan S. R. and Ibrahim, J. (2003). The estrogenic and cytotoxic effects of the extracts of Labisia pumila var. alata and Labisia pumila var. pumila in vitro. Malaysian Journal of Medicine and Health Sciences, 1: 53-60.

4. Institute for Medical Research (2002). Estrogenic and androgenic activities of Kacip Fatimah (Labisia pumila). Ministry of Health Malaysia, Kuala Lumpur: pp. 8.

5. Bhathena, S. J. and Velasquez, M. T. (2002). Beneficial role of dietary phytoestrogens in obesity and diabetes. The American Journal of Clinical Nutrition, 76(6): 1191-1201.

6. Ayida, A. W., Wan Norzaimoon, W. M., Farihan, H. S. and Azian, A. L. (2007). Effect of ovariectomy, $L$. pumila var. alata treatment and estrogen replacement therapy on the morphology of adipose tissue in ovariectomized Sparague Dawley rats. Journal of Medicine, (1): 1-7.

7. Al-Wahaibi, A., Wan Nazaimoon W. N. Norsyam, W. N., Farihah, H. S. and Azian, A. L. (2008). Effect of water extracts of Labisia pumila var. alata on aorta of ovariectomized Sprague-Dawley rats. Pakistan Journal of Nutrition, 7: 208-213. 


\section{Norliza et al: LIQUID CHROMATOGRAPHY TANDEM MASS SPECTROMETRY FOR THE DETECTION AND VALIDATION OF QUERCETIN-3-O-RUTINOSIDE AND MYRICETIN FROM FRACTIONATED Labisia pumila var. alata}

8. Singh, R. P., Murthy, C. K. N. and Jayaprakasha, G. K. (2002). Studies on the antioxidant activity of pomegranate (Punicagranatum) peel and seed extracts using in vitro models. Journal of Agricultural and Food Chemistry, 50: 81-86.

9. Fathilah, S. N., Mohamed, N., Muhammad, N., Mohamed, I. S., Soelaiman, I. N. and Shuid, A. N. (2013). Labisia pumila regulates bone-related genes expressions in postmenopausal osteoporosis model. BMC Complementary and Alternative Medicine, 13: 217.

10. Manda, V. K., Dale, O. R., Awortwe, C., Ali, Z., Khan, I. A., Walker, L. A. and Khan, S. I. (2014). Evaluation of drug interaction potential of Labisia pumila (Kacip Fatimah) and its constituents. Frontiers in Pharmacology, 5: 178.

11. Choi, H. K, Kim, D. H., Kim, J. W., Ngadiran, S., Sarmidi, M. R. and Park, C. S. (2010). Labisia pumila extract protects skin cells from photoaging caused by UVB irradiation. Journal of Bioscience. Bioengineering, 109: 291-296.

12. Chua, L. S., Lee S. Y., Abdullah., N., Sarmidi. M. R. (2012). Review on Labisia pumila (Kacip Fatimah): Bioactive phytochemicals and skin collagen synthesis promoting herb. Fitoterapia, 83(8): 1322-1335.

13. Karimi, E., Jaafar, H. Z. E. and Ahmad, S. (2011). Phytochemical analysis and antimicrobial activities of methanolic extracts of leaf stem and root from different varieties of Labisia pumila Benth. Molecules, 16: 44384450 .

14. Ibrahim, M. H and Jaafar, H. Z. E. (2011). Enhancement of leaf gas exchange and primary metabolites under carbon dioxide enrichment up-regulate the production of secondary metabolites in Labisia pumila seedlings. Molecules, 16: 3761-3777.

15. Ali, Z. and Khan, I. A. (2011). Alkyl phenols and saponins from the roots of Labisia pumila (Kacip Fatimah). Phytochemistry, 72: 2075-2080.

16. Stone, B. C. (1988). Notes on the genus Labisia Lindl (Myrsinaceae). Malayan Nature Journal, 42: 43-51.

17. Karimi, E. and Jaafar, H. Z. E. (2011). HPLC and GC-MS determination of bioactive compounds in microwave obtained extracts of three varieties of Labisia pumila Benth. Molecules, 16: 6791-6805.

18. Avula, B., Wang Y. H., Ali Z., Smillie, T. J. and Khan, I.A. (2011). Quantitative determination of triterpene saponins and alkenated-phenolics from Labisia pumila using LC-UV/ELSD method and confirmation by LCESI-TOF. Planta Medica, 77: 1742-1748.

19. Al-Mekhlafi, N. A., Shaari, K., Abas, F, Kneer, R., Jayaseela Jeyaray, E. and Stanslas, J. (2012). Alkenylresorcinols and chytotoxic activity of constituents isolated from Labisia pumila. Phytochemistry, 80: 42-49.

20. Mohd Nazrul Hisham, D., Mohd Lip, J., Mohd Noh, A., Normah, F. and Nurul Nabilah, M. F. (2011). Identification and isolation of methyl gallate as a polar chemical marker for Labisia pumila Benth. Journal of Tropical Agriculture and Food Science, 39: 279-284.

21. Abdullah, F., Sui K. L., Man, S., Tan, A. I., Tan, H. P. and Abdullah, Z. (2012). Characterization and identification of Labisia Pumila by multi-steps infrared spectroscopy. Vibrational Spectroscopy, 62: 200-206.

22. Chua, L. S., Norliza, A. L., Lee, S. Y., Lee, C. T. and Sarmidi, M. R. (2011). Flavonoids and phenolic acids from Labisa pumila (Kacip Fatimah). Food Chemistry, 127: 1186-1192.

23. Chua, L. S. (2013). A review on plant-based rutin extraction methods and its pharmacological activities. Journal of Ethnopharmacology, 150(3): 805-817.

24. Anelwew (2014). The use of rutin in anti-aging cosmetics. Retrieved from http://www.articlesnatch.com/ article//3702816\#.U6PlHfmSxqW [14 June 2014,]

25. Mendez, J., Bilia A. R and Morelli, I. (1995). Phytochemical, investigations of Licania genus, flavonoids and triterpenoids from Licaniapittieri. Pharmaceutica Acta Helvetiae, 70: 223-226.

26. Aherne, S. A. and O'Brien. (1999). The flavonoids, myricetin, quercetin and rutin, protect against cholestan-3p, 5cr, 6p-triol- induced toxicity in Chinese hamster ovary cells in vitro. Nutrition Research, (19)5: 749-760.

27. Abdah, M. S. N., Sarmidi, M. R., Yaakob, H. and Ware, I. (2014). Fractionation of Labisia pumila using solidphase extraction for extraction of gallic acid. Jurnal Teknologi, 69:465-468.

28. Barwick, V. (2016). Eurachem/CITAC Guide: Guide to quality in analytical chemistry: An aid to accreditation ( $3^{\text {rd }}$ edition). Available from www.eurachem.org.

29. Armbruster, D. A., Tillman M. D. and Hubbs, L. M. (1994). Limit of detection (LQD)/limit of quantitation (LOQ): Comparison of the empirical and the statistical methods exemplified with GC-MS assays of abused drugs. Clinical Chemistry, 40(7): 1233-1238. 
30. Hollecker, L., Maurizio P. M., Filippino, G., Scruglia, S., Pinnab, B., Argiolas, F. and Mariano M. M. (2009). Simultaneous determination of polyphenolic compounds in red and white grapes grown in Sardinia by high performance liquid chromatography-electron spray ionisation-mass spectrometry. Journal of Chromatography A, 1216: 3402-3408.

31. Abad Garcia, B., Berrueta, L. A., Garmon-Lobato, S., Gallo, B. and Vicente, F. (2009). A general analytical strategy for the characterization of phenolic compounds in fruit juices by high-performance liquid chromatography with diode array detection coupled to electrospray ionization and triple quadrupole mass spectrometry. Journal of Chromatography A, 1216: 5398-5415.

32. Celli, G. B., Pereira-Netto, A. B. and Beta, T. (2010). Comparative analysis of total phenolic content, antioxidant activity, and flavonoids profile of fruits from two varieties of Brazilian cherry (Eugenia uniflora L.) throughout the fruit developmental stages. Food Research International, 44(2011): 2442-2245.

33. Pikulski, M. and Brodbelt, J. S. (2003). Differentiation of flavonoid glycoside isomers by using metal complexation and electrospray ionization mass spectrometry. Journal American Society Mass Spectrometry, 14: 1437-1453.

34. Simirgiotis, M. J., Bórqueza, J. and Schmeda-Hirschmannb, G. (2013). Antioxidant capacity, polyphenolic content and tandem HPLC-DAD-ESI/MS profiling of phenolic compounds from the South American berries Lumaapiculata and L. chequén, Food Chemistry, 139(1-4): 289-299.

35. Yun, L., Bin, W., Zhixiong, L., Ting, H., Mingcang, C., Yingzi, T., Jian, J. and Chenggang, H. (2012). Metabolite identification of myricetin in rats using HPLC coupled with ESI-MS. Chromatographia, 75(11): 655-660.

36. Saldanha, L. L.,Vilegas, W. and Dokkedal, A. L. (2013). Characterization of flavonoids and phenolic acids in Myrciabella cambess using FIA-ESI-IT-MSn and HPLC-PAD-ESI-IT-MS combined with NMR. Molecules, 18: 8402-8416.

37. Koponen, J. M., Happonen, A. M., Auriola, S., Kontkanen, H., Buchert, J. and Poutanen, K. S. (2008). Characterization and fate of black currant and bilberry flavonols in enzyme-aided processing. Journal of Agriculture and Food Chemistry, 56(9): 3136-3144. 